Volume 13

Number 12013

Article 3

December 2013

\title{
Providing Care at the End of Life: An Examination of Biblical Principles
}

Charles D. Snyder

Cedarville University, charlessnyder@cedarville.edu

DigitalCommons@Cedarville provides a publication platform for fully open access journals, which means that all articles are available on the Internet to all users immediately upon publication. However, the opinions and sentiments expressed by the authors of articles published in our journals do not necessarily indicate the endorsement or reflect the views of DigitalCommons@Cedarville, the Centennial Library, or Cedarville University and its employees. The authors are solely responsible for the content of their work. Please address questions to dc@cedarville.edu.

\section{Recommended Citation}

Snyder, Charles D. (2013) "Providing Care at the End of Life: An Examination of Biblical Principles," CedarEthics: A Journal of Critical Thinking in Bioethics: Vol. 13 : No. 1 , Article 3.

DOI: $10.15385 /$ jce.2013.13.1.3

Available at: http:// digitalcommons.cedarville.edu/cedarethics/vol13/iss1/3 


\title{
Providing Care at the End of Life: An Examination of Biblical Principles
}

Browse the contents of this issue of CedarEthics: A Journal of Critical Thinking in Bioethics.

\begin{abstract}
In our modern age, the line between life and death has become more and more blurred. This often leaves the family and friends of terminally ill patients to wonder how to make decisions about their loved one in the light of their Christian faith. The growth of modern life-prolonging technologies has given rise to a plethora of new and confusing technical terms. This paper will attempt to wade through these terms and definitions by looking at several scriptural situations dealing with the end of life. I will then highlight the biblical principles that must transcend every end of life situation. I should note that many end of life issues deal with technologies that simply did not exist during biblical times. Scripture will therefore not speak directly to every issue. That does not mean, however, that the truths to which the Bible speaks are not still relevant.
\end{abstract}

Keywords

End of life care, biblical principles

Creative Commons License

(ब) (1) $\Theta$

This work is licensed under a Creative Commons Attribution-Noncommercial-No Derivative Works 3.0 License.

Follow this and additional works at: http://digitalcommons.cedarville.edu/cedarethics

Part of the Bioethics and Medical Ethics Commons 


\title{
Providing Care at the End of Life: An Examination of Biblical Principles
}

\author{
Charles D. Snyder \\ Cedarville University
}

$\mathrm{I}$

n our modern age, the line between life and death has become more and more blurred. This often leaves the family and friends of terminally ill patients to wonder how to make decisions about their loved one in the light of their Christian faith. The growth of modern life- prolonging technologies has given rise to a plethora of new and confusing technical terms. This paper will attempt to wade through these terms and definitions by looking at several scriptural situations dealing with the end of life. I will then highlight the biblical principles that must transcend every end of life situation. I should note that many end of life issues deal with technologies that simply did not exist during biblical times. Scripture will therefore not speak directly to every issue. That does not mean, however, that the truths to which the Bible speaks are not still relevant.

My first example of a biblical end of life situation comes from 1 Samuel 31. This is the account of the death of King Saul. In the course of a battle with the Philistines, Saul is wounded by the enemies' archers. Before they are able to overtake him, Saul asks his sword bearer to run him through. The sword bearer will not do it, so Saul falls upon his own sword and thus ends his life. It is important to note that verse 3 tells us that "they wounded him critically," and also that Saul took his own life out of fear that "these uncircumcised fellows will come and run me through and abuse me.” This is truly a complex situation with cultural mores playing a role.

Gauld sheds some light on the issue in his commentary on 1 Samuel by noting "The relevance of an ancient battlefield to modern medical issues is not immediately obvious. And yet, like every medic, the normal duty of the armor-bearer is to help his charge stay alive - but this one is asked by the king to do the opposite" (Gould, 2011). In this situation, Saul is criticallywounded and faces imminent death, so he takes his own life. The Bible neither praises this as a courageous and morally correct act, nor condemns it as sin. The passage simply provides the facts of a narrative, not passing judgment on an end of life situation. The more important issue, as noted by Gould, may be the sword bearer's refusal to end Saul's life. However this may speak to his fear of dishonoring God by killing His anointed, just as much as his refusal to take a life. Although some good principles can be gleaned from this passage, there is not enough information here to use this as a guide in modern end of life situations.

My next example is found in Job chapter 2. Although this passage does not result in the death of Job, it still speaks wisdom into the situation. At the beginning of Job, God has given Satan a free pass to persecute Job in order to test his faith. The only stipulation is that Job's life cannot be taken. At the point of this passage, Job has lost all of his children, all of his wealth and is heavily afflicted with sores from his head to his feet. Though some try to hypothesize what disease afflicted Job, the passage does not give the reader enough information to be able to tell. What we do know is that they were extremely painful and burdensome. In verse nine, Job's wife asks him “Are you still holding on to your integrity? Curse God and die!” Job responds (v. 
10): “'You are talking like a foolish woman. Shall we accept good from God and not trouble?' In all this, Job did not sin in what he said."

It should be noted that Job did not have a terminal illness, although an argument could be made that his quality of life was gone. He had overwhelming pain and he had lost everything that he held dear to him. Yet in spite of all this, Job does not look for death as a way out of his situation. He accepts the lot that God has given him, and we are told that he did not sin in this.

It may be a stretch to apply this story to all contemporary end of life situations by saying that health care professionals and the family of terminally ill patients should never accept death, just because Job accepted his lot and persevered. Yet there is definitely a lesson to be learned here. Job is a great example of a man who stayed faithful to God even when his life was full of pain and his situation seemed without hope.

From these two narratives and other passages, we can find several principles to help guide those involved in end of life situations to make God-honoring decisions. The first principle is that God is sovereign. The passage from Job makes this clear. One commentator has said, "Rejecting his wife's outrageous urging, Job affirms what is theologically normative, namely, the absolute sovereignty of God, who is the creator of all that is - both the good and the bad. In so doing, Job appears to reiterate his previous acknowledgement that 'YHWH gives, and YHWH takes away' (1:21)” (Seow, 2013).

It is clear throughout scripture that God is in control and is working his ultimate plan, and end of life situations are not exempt from this. Some examples of God's sovereignty include 1 Corinthians 6:19-20, which states "Do you not know that your body is a temple of the Holy Spirit, who is in you, whom you have received from God? You are not your own; you were bought at a price. Therefore honor God with your body.” This demonstrates God's control over our bodies as well as speaks to our responsibility to honor God with what we do with our body.

Romans 8:28, Psalm 115:3, Proverbs 21:1 and many other verses also speak to God's sovereign control over the universe and our lives. Christians struggling with end of life decisions must always keep in mind that the Almighty God is in control and through everything his purpose is carried out. (Sullivan, 2005)

The second major principle that must be kept in mind is that God has created humans in his image, and therefore human life is sacred. We see this as far back as the creation account. Genesis 1:27 reads "So God created man in his own image, in the image of God He created him; male and female He created them." Also in Genesis 9:6 God states "Whoever sheds the blood of man by man shall his blood be shed; for in the image of God has God made man.” The emphasis in these passages is that God has created man in the image of himself, and Genesis 9 also shows us the importance and emphasis God places on human life. When dealing with patients nearing the end of their lives it is absolutely critical that they are cared for in a respectful and loving manner.

No matter how desperate or dark the lives of patients may seem, they are still creatures formed in the image of the Almighty. No physical distortion can take that away from them. It is too easy to lose sight of this when patients are near the end and start losing some of their normal 
functions. However a lack of function does not negate their personhood. By respecting God's image in their patients, care takers can make better decisions concerning their care.

A third major principle is that as believers we know that this life is not the end, and that eternity awaits us after death. Scripture is clear throughout that Christ's redemptive work on the cross has made us right with God; we now have a way to enjoy eternity in heaven with him. As Christians, there is a dichotomy between wanting to preserve life here on earth and desiring life

in heaven. We know that death is not the end but only an escape from our fallen bodies.

However when dealing with end of life situations, we must remember that, while we do hold to the

ultimate truth, not everyone shares a Christian perspective on this. Englehart has said, "This difference in focus can cause misunderstandings and conflicts at the bedside. A person who knows there is eternal life will approach end-of-life decisions quite differently from one who regards this present life as all there is” (Engelhardt \& Smith, 2005). We must understand this difference in viewpoint, and use the opportunity presented by these tough situations to minister to the people most in need of the love of Christ. As Christians we know that there is a hope of a life even beyond death and we must try to share this hope with those around us who are hurting.

End of life situations are often confusing, and it is sometimes difficult to decide the correct course of action. By keeping in mind the principles that God is sovereign, human life is sacred, and death is not the end, as well as using biblical examples such as Job, we can make the best decisions. This allows care takers to honor God and to honor those in the midst of tough end of life situations.

\section{References}

Engelhardt, H., \& Smith Iltis, A. (2005). End-of-life: the traditional Christian view. Lancet, 366(9490), 1045-1049. doi:10.1016/S0140-6736(05)67383-7

Gould, A. (2011). I \& II Samuel. (pp. 348-360). Louisville: Westminster John Knox Press. Seow, C. L. (2013). Job 1-21 Interpretation and Commentary. (p. 297). Grand Rapids, MI: William B. Eerdmans Publishing Company.

Sullivan, D. (2005). Euthanasia Versus Letting Die: Christian Decision-making in Terminal Patients. Ethics and Medicine, 21(2), 